\title{
Groundwater Quality Assessment Using Multivariate Analysis and Water Quality Index in some Saline Fields of Central Nigeria
}

\author{
N. D. Umar ${ }^{\mathrm{a}}$, O. V. Omonona ${ }^{\mathrm{b}, *}$, C. O. Okogbue \\ ${ }^{a}$ Department of Geology, Federal University of Lafia \\ ${ }^{b}$ Department of Geology/Geophysics, Alex Ekwueme Federal University, Ndufu Alike Iko \\ ${ }^{c}$ Department of Geology, University of Nigeria
}

\begin{abstract}
The groundwater of Awe-Keana saline fields central Nigeria was studied to investigate physicochemical processes that influence its groundwater chemistry and quality and hence determine its quality for drinking and irrigation purposes. Twenty groundwater samples were collected from hand dug wells and borehole for the purpose of identifying the hydrochemical characteristics and assessing the quality of groundwater of the Awe-Keana saline fields. Principal component analysis was performed to identify the hydrochemical controlling processes while water quality index (WQI) was used to determine the overall quality of the water samples. Multiple regression analysis however, revealed the parameter(s) that impact the overall water quality the most. The results showed that the chemical compositions of the groundwater of the area is influence by weathering of host rocks, salinity and anthropogenic activities. Four hydrochemical facies were deciphered $\left(\mathrm{Ca}-\mathrm{Mg}-\mathrm{HCO}, \mathrm{Na}-\mathrm{K}-\mathrm{HCO}, \mathrm{Na}_{3} \mathrm{~K}-\mathrm{Cl}-\mathrm{SO}_{4}\right.$, and $\mathrm{Ca}-\mathrm{Mg}-\mathrm{Cl}-\mathrm{SO}_{4}$ ) and this revealed the diversity in the chemical controlling processes that yield different facies. Two clusters of water groups were identified from cluster analysis, namely, groundwater characterized with very high salinity, high nitrate contamination and high $C a$, $\mathrm{Cl}, \mathrm{Na}$, and $\mathrm{HCO}_{3}$ ionic concentrations and groundwater with high $\mathrm{Mg}, \mathrm{K}$, and $\mathrm{SO}_{4}$ ionic concentrations. Saturation indices in relation to different minerals showed that precipitation and dissolution processes gave rise to the concentrations of different ions in the groundwater. Water quality assessment showed that about $85 \%$ of the groundwater of the area is unsuitable as drinking water but, generally suitable for irrigation. Multiple regression analysis revealed that $\mathrm{NO}_{3}$ ion among the hydrochemical parameters measured was observed to be the major pollutant in groundwater of the study area.
\end{abstract}

\section{DOI:10.46481/jnsps.2021.183}

Keywords: Awe-Keana, Multivariate analysis, Saline field, Water quality, Water quality index

Article History :

Received: 17 March 2020

Received in revised form: 17 June 2021

Accepted for publication: 16 July 2021

Published: 29 November 2021

(C)2021 Journal of the Nigerian Society of Physical Sciences. All rights reserved. Communicated by: O. J. Abimbola

\section{Introduction}

The Awe - Keana saline fields is located in parts of the Central Benue Trough (CBT), Nigeria. The occurrence of saline groundwater as springs, lakes and ponds is common in parts of

\footnotetext{
${ }^{*}$ Corresponding author tel. no: $+(234) 8036145840$

Email address: victor .omonona@funai.edu.ng (O. V. Omonona)
}

the sedimentary basin. Different hypothesis has been given to explain the origin of saline water in the Trough, however, the theories postulated by [1] are widely acceptable. The saline groundwater in the southern and central sections of the Benue Trough is frequently associated with tectonic elements such as intrusive and mineralized veins. Prominent outcrops which commonly support local table salt industries are found in the CBT. These industries serve as sources of employment to the 
locals who engage in the table salt production business.

The area is also known for agricultural activities, mainly crop production. Domestic and agricultural water supply in the Central Benue Trough is largely through groundwater sources. Groundwater supports human existence on earth therefore, its quantity and quality are very important with regard to drinking, irrigation and industrial water supplies. The world over, there is decline on the available of high-quality groundwater for human consumption [2]. This quality can be impacted significantly by land usage, geology and anthropogenic activities.

Groundwater is preferred to surface water because it is readily available throughout the year as surface water in the area usually becomes unavailable during the long dry season. Besides, it is cheaper to access groundwater than exploring for and exploiting surface water. Groundwater is also more potable and not easily contaminated as surface water but is more difficult to remediate a contaminated groundwater source. However, advances in the physicochemical characteristics of groundwater with respect to drinking and agricultural purposes has not been prioritized, as water from these hand-dug wells and boreholes are put to use without any quality consideration and hence its health implications. The determination of groundwater quality for human consumption is important for the wellbeing of the increasing population [3]. It is important therefore to establish those quality criteria for human health and food security considering the growing population and increased agricultural activities in the study area. It is thus pertinent to know the possible sources of contaminants and quality of groundwater supply for various purposes in area.

[4] identified natural processes as the controlling factors of the hydrochemistry of groundwater chemistry while, anthropogenic contaminations, natural mineralisation and cation exchange as factors controlling the hydrochemistry. Groundwater quality for drinking and agricultural or other purposes has been studied by [5, 6 and 7]. Water quality index (WQI) have been identified as an important technique for define groundwater quality and its potability. [2, 6 and 8] used the WQI to classify groundwater for drinking.

Previous works on groundwater quality for drinking and agricultural or other purposes around the Benue Trough are available likewise studies on the hydrochemical characteristics of groundwater [5, 6 and 7] but no hydrochemical work has been carried out around the saline field of the Awe-Keana region. This present study seeks to investigate physicochemical processes that influence the groundwater chemistry and quality, decipher the underlying contaminants imparting the quality of groundwater of the area and hence determine its quality for drinking and irrigation purposes.

\section{The Study Area}

\subsection{Location}

Awe-Keana lies within latitudes $8^{\circ} 06^{\prime} N$ to $9^{\circ} 09^{\prime} N$ and longitudes $8^{\circ} 47^{\prime} E$ to $9^{\circ} 09^{\prime} E$. The area forms part of the saline fields in Central Nigeria (Figure 1). It is generally a lowland area with few scattered hills with elevation that ranges from 115 - $165 m$ above mean sea level. The River Keana and River Tunga, which are major tributaries of the River Benue constitute the main drainage system of the area. The climatic condition is made up of two major and distinct seasons: a wet season and a dry season. The former lasts from May to October while the latter lasts from November to April. The mean annual rainfall varies between 1000 and $1500 \mathrm{~mm}$ and the relative humidity between 60 and $80 \%$. The average annual humidity and temperature are $70 \%$ and $28.50{ }^{\circ} \mathrm{C}$ respectively [9].
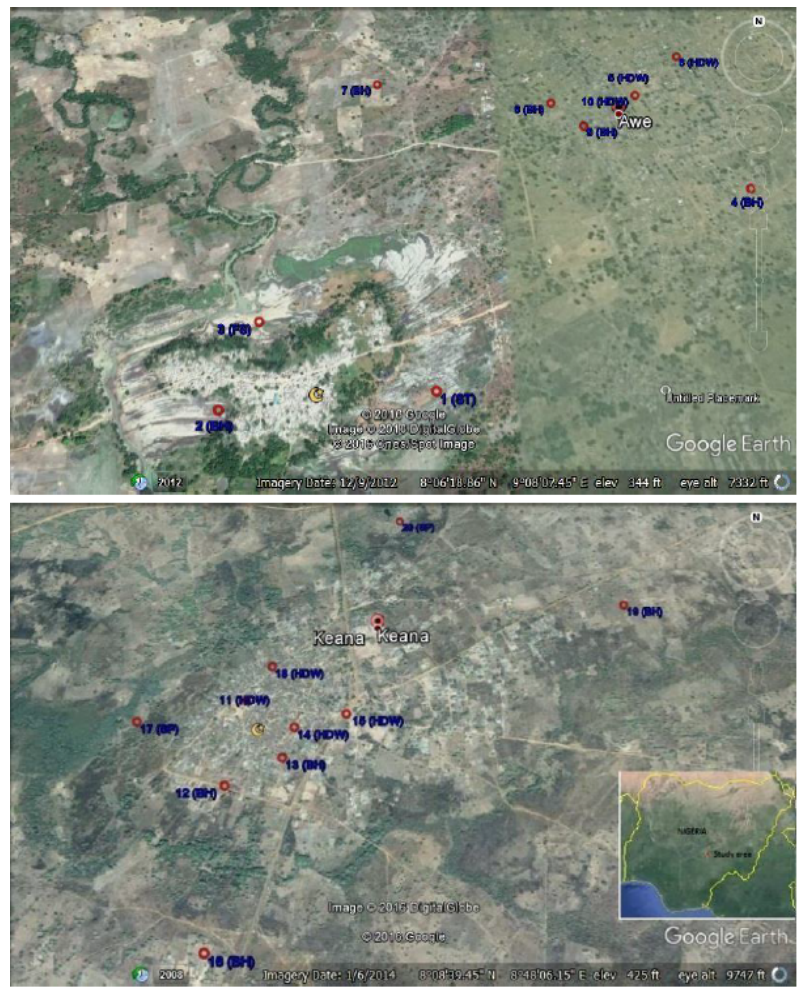

Figure 1. Google Earth view of the Awe-Keana area showing the sample collection points.

\subsection{Geology and Hydrogeology}

In the Middle Benue Trough, six Upper Cretaceous lithogenic formations (Asu River Group, Ezeaku Formation, Keana Formation, Awe Formation, Awgu Formation and Lafia sandstone) comprise the stratigraphic succession (Figure 2). The Asu River Group comprises of limestones, shales, micaceous siltstones, mudstones and clays [10, 11 and 12]. These are overlain by the Cenomanian-Turonian Ezeaku Formation which deposition marked the beginning of marine transgression in the Late Cenomanian which took place in a presumably shallow marine coastal environment. The sediments are made up mainly of calcareous shales, micaceous fine to medium friable sandstones and beds of limestones which are in places shelly. The Keana Formation resulted from the Cenomanian regression which deposited fluviodeltaic sediments. The Formation consists of cross-bedded, coarse grained feldspartic sandstones, occasional conglomerates, and bands of shales and limestones towards the top. Massive outcrops occur at Keana, Azara and Daudu. This was followed by the Awe Formations which was deposited as passage 
(transitional) beds during the Late Albian Early Cenomanian regression. Its typical sections occur around the town of Awe, where [10] estimated the thickness to be about $100 \mathrm{~m}$. The formation consists of flaggy, whitish, medium to coarse grained calcareous sandstones, carbonaceous shales and clays.

The Late Turonian-Early Santonian coal-bearing Awgu Formation lies conformably on the Awe Formation. The deposition of the Awgu Formation marked the end of marine sedimentation in this part of the Benue Trough. The formation is made up of bluish-grey to dark-black carbonaceous shales, calcareous shales, shaley limestones, limestones, sandstones, siltstones, and coal seams. The major outcrop of the coal-bearing Awgu Formation is at the bank of River Dep in Shankodi, $7 \mathrm{~km}$ to the west of the village of Jangwa.

The post-folding Campano-Maastrichtian Lafia Formation ended the sedimentation in the Middle Benue Trough, after which widespread volcanic activities took over in the Tertiary. It is lithologically characterized by ferruginized sandstones, red, loose sands, flaggy mudstones, clays and claystones. Outcrops and sections of the Lafia Formation occur in and around the town of Lafia, and along the bank of River Amba on the LafiaDoma Road.

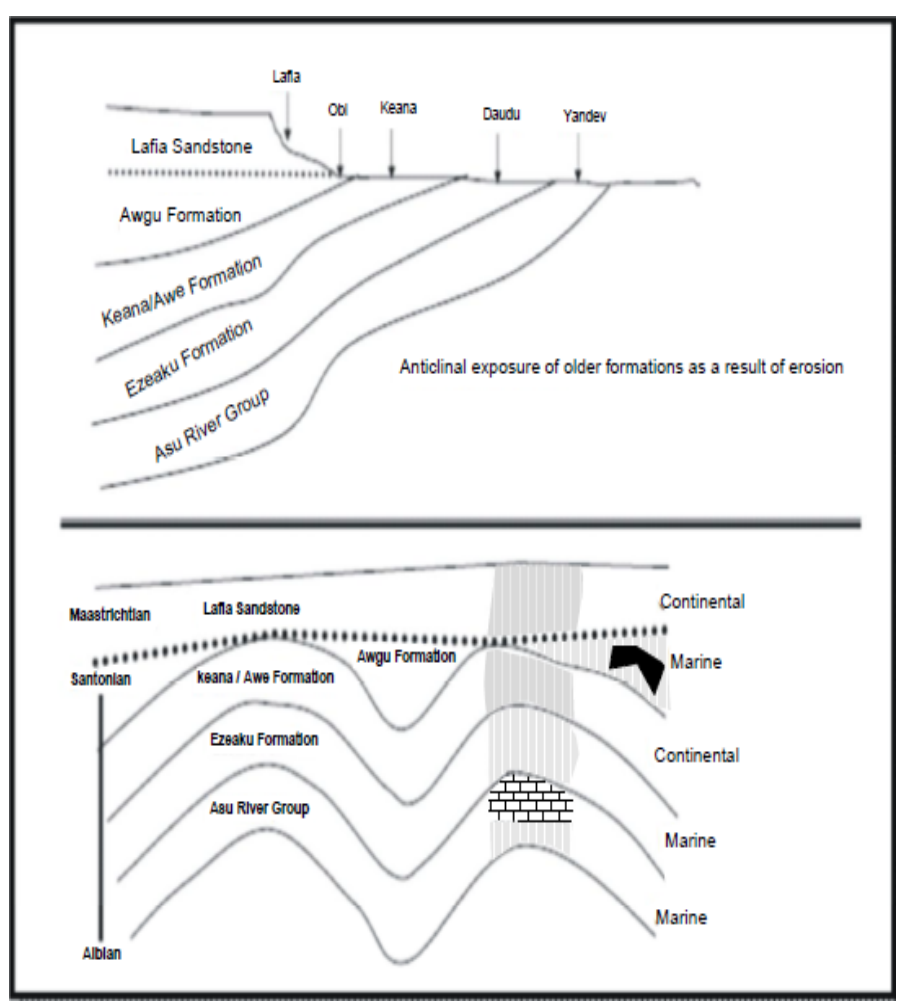

Figure 2. Stratigraphic succession in the Middle Benue Trough (Obaje, 2009).

The Awe-Keana saline field of the CBT is underlain by the following geological sequence: the Asu River Group (marine), the Ezeaku (marine), the Keana/Awe Formation (continental) the Awgu Formation (marine) and the Lafia Sandstone (continental). Detailed discussions on the geology of the Central Benue Trough were presented by many authors notably [10,
11 and 12]. Awe-Keana brine fields are known to have very strange and difficult hydrogeological situations. These conditions arise from the fact that most of the potential aquifers are either limited in extent, thinly developed with consistent clay and shale interbeddings or even highly indurated that only the development of secondary voids created by fractures, joints and solutions channels can attract hydrogeological interest. The stratigraphic sequence (Table 1) shows that the study areas are made up of alternate shale and sandstone horizons which are suspected to correspond to the sources of the saline and freshwater respectively.

Ezeaku, Keana and Awe Formation aquifers are the main aquifer units in study area [13]. The uppermost aquifer is the sandstone member of the Ezeaku Formation which is composed of series of shale-limestone and sandstone beds. Keana Formation aquifer is composed of more heterogeneous, massive and predominantly fine, coarse and pebbly sandstone beds. Keana Formation is a good aquifer but is limited in extent which renders it unproductive for groundwater exploration. However, Keana together with Ezeaku Formations form a very thick productive aquifer when encountered in a borehole.

Awe Formation aquifer is the lowest aquifer and is composed of series of shale and porous sandstone beds and is highly productive. However, the presence of salt in it renders it unfavourable for groundwater exploration as the water from wells tapping the aquifer around Old Awe Town (Tsohon Gari) show high saline concentration because of the out-cropping brinebearing Awe Formation [14].

\section{Materials and Methods}

Twenty (20) groundwater samples were collected from shallow hand dug wells and boreholes in the study area. Sampling was done early in the morning before water abstraction commenced by the residents of the study area. The study area was gridded into ten quadrants for even distribution of sample locations and two samples were collected from each quadrant at an arbitrary distance. At each location, two water samples were collected and filtered in situ through a $0.45 \mu \mathrm{m}$ membrane filter, collected in labelled $125 \mathrm{ml}$ bottles and kept under cold condition for the detection of anions and cations. Samples for cation analytes were acidified to a $\mathrm{pH}$ less than 2 with concentrated nitric acid in water solution at $0.15 \%$ concentration by weight.

Transient physicochemical parameters (temperature, total dissolved solids, electrical conductivity and redox potential) were measured immediately in the field using Portable T/pH/EC /TDS meter (H19813-5 model) and portable Eh meter while the cations and anions were collected in a fresh new high-density polyethylene (HDPE) bottles for laboratory analysis. The concentrations of the cations were determined using ICP-ES/ICPMS at Acme Analytical Laboratories Ltd, Canada, while the anions were analyzed using HACH DR 2000 spectrophotometer at UNICEF assisted Water Supply and Sanitation Laboratory, Ibadan, Nigeria. [15] quality assurance programme was employed to check the validity of the field measurements and laboratory analytical results. Quality control measures applied in- 
Table 1. Hydrostratigraphic units of Rocks in the study areas (Modified from Offodile, 2002).

\begin{tabular}{|c|c|c|c|c|}
\hline EPOCH & AGE & GEOLOGIC FORMATION & ROCK UNIT & AQUIFERS \\
\hline & Santonian-Campanian & Volcanic & \multirow{8}{*}{$\begin{array}{c}\text { Fine to coarse grained, } \\
\text { friable and feldspartic sandstone, } \\
\text { brownish at top and whitish } \\
\text { at depth. } \\
\text { Greybedded shale with occasional } \\
\text { sandstone bed and limestone. } \\
\text { Thick calcareous shales, } \\
\text { micaceous and fine to } \\
\text { medium grained sandstones. } \\
\text { Crystalline fine, coarse } \\
\text { and pebbly sandstone. } \\
\text { Flaggy, whitish, medium } \\
\text { to coarse grained feldspartic } \\
\text { sandstones, calcareous sandstones, } \\
\text { limestone interbedded with } \\
\text { carbonaceous shale. } \\
\text { Marine shales, clays } \\
\text { siltstones and mudstones. }\end{array}$} & \multirow{6}{*}{ Aquifer } \\
\hline \multirow[t]{6}{*}{ Cretaceous } & Maastrichtian & Lafia Formation & & \\
\hline & Coniacian & Awgu Formation & & \\
\hline & $\begin{array}{l}\text { Late Turonian- } \\
\text { Early Turonian }\end{array}$ & Ezeaku Formation & & \\
\hline & Late Cenomanian & Keana Formation & & \\
\hline & & & & \\
\hline & Early Cenomanian & Awe Formation & & \multirow[t]{3}{*}{ Aquifer } \\
\hline Early Cretaceous & Mid-Late Albian & Asu River Group & & \\
\hline Pre Cambrian & & $\begin{array}{l}\text { Basement Complex } \\
\text { and Meta-sediments }\end{array}$ & Crystalline rock & \\
\hline
\end{tabular}

cluded the use of blank samples and estimation of the cation-anion ratios [16, 17, 18 and 19].

Saturation index of calcite, dolomite, halite, gypsum, siderite, and hematite was estimated using pH-REEQC 3.3.8-11728. WQI was calculated according to [3, 20 and 21 and was used to classify groundwater quality into the different degree of quality on the overall quality of water for human consumption [22 and 23].

Statistical analyses were performed using Statgraphics Centurion XVI.I which includes (mean, minimum, maximum, coefficient of variation, and standard deviation). Pearson's correlation matrix, principal components analysis (PCA), cluster analysis (CA), and multiple regression analysis. PCA and CA were carried out using standardized data. Standardization of the data for the statistical tests was done in order to resolve the effect of differences in the units of measurements and large variations between the data units. PCA were performed on the correlation matrix of the data and the number of extracted principal components was based on a minimum Eigen value of 1.0.

CA was carried out based on Ward's method and the Squared Euclidean distance metric mode. The clusters defined by the CA were based on the similarity in chemical compositions of the various water sampling stations [24]. Multiple regression analysis was conducted on the data to determine the parameter(s) that most influenced the character of the WQI. WQI values were the dependent variable while the concentrations of the parameters used in the estimation of WQI were the independent variables. The model was fitted upon the forward stepwise selection procedure.

\section{Results and Discussion}

\subsection{Physicochemical characteristics}

The summary of the results of the hydrochemical parameters along with the WHO standard for drinking water are presented in Table 1 . The $\mathrm{pH}$ of the groundwater samples ranges from 5.52 to 7.72, with a mean value of 6.46 . Low $\mathrm{pH}$ is predominant around Awe area and could be attributed to the presence of humic shale found around that area, while the low $\mathrm{pH}$ around Keana could attributed to photosynthetic processes. Water with low $\mathrm{pH}$ (below 6.5) is unacceptable for drinking purposes, as such water is reported to cause acidosis [25 and 26]. The redox potential (Eh) value ranges from 8 to $281 \mathrm{mV}$ with an average value of $175.3 \mathrm{mV}$. It was observed that Eh has negative correlations with all the physicochemical parameters except $\mathrm{CO}_{3}$ and $\mathrm{SO}_{4}$. The positive correlation coefficient values of $\mathrm{CO}_{3}$ and $\mathrm{SO}_{4}$ with Eh may be attributed to the high tendency of $C$ and $S$ to participate in redox reactions because of their variable oxidation states. Eh has significant negative correlation coefficient values (-0.519) with $C l$ and salinity. This shows that high salinity and chloride concentration in groundwater in the area is favoured under a low redox condition (an anoxic environment).

Electrical conductivity (EC) values ranged from 56.1 to 1059 $\mu \mathrm{S} / \mathrm{cm}$ with a mean value of 591.45 while total dissolved solids (TDS) ranged from 37.58 to $709.53 \mathrm{ppm}$ with a mean value of 396.27. The higher variations in the EC value are partly as a result of the wide variation in the water table and saturated zone in the area and partly due to the effect of increased temperature and pressure with depth which increased the rate of reaction and dissolution of ions. A linear relationship occurs between EC and TDS (correlation coefficient of 1.0). This imply that 
TDS is the dominant factor in the EC of the study area. About $65 \%$ of the groundwater samples from the area have EC values above the stipulated guideline value while $40 \%$ of the water samples have TDS values above the guideline value [24].

Salinity values of the groundwater samples ranged from 0.011 to $15.510 \mathrm{ppt}$ with a mean value of 0.885 . At Awe area, high salinity is confined to the southwest zone (salinity value ¿ 15 ppt was measured). However, in Keana, high salinity is spread throughout the area (Figure 2).

\subsection{Cation and anion: concentrations and relationships}

The concentration of sodium varied ranges from 4.22 to $3024 \mathrm{ppm}$, potassium from 0.84 to $79.18 \mathrm{ppm}$ while calcium and magnesium varied from 3.63 to $137.30 \mathrm{ppm}$ and 0.96 to $48.66 \mathrm{ppm}$ respectively. Magnesium concentration in all the groundwater studied is below the guideline value of $50 \mathrm{ppm}$ while $25 \%$ of the water samples have calcium concentrations above the [24] guideline value of $75 \mathrm{ppm}$. Bicarbonate concentrations varied from < $1 \mathrm{ppm}$ (below detection limit) to $888.2 \mathrm{ppm}$, chloride concentration ranges from 5.99 to 8584.95 ppm while sulphate concentration range from 2 to $60 \mathrm{ppm}$ (Table 2). Generally, there is high variability in the concentrations of the major ions which could be the results of differences in the geologic units and lithogenic processes of the aquifers, recharge rate variability, and anthropogenic factors. The following cation-anion pairs with correlation coefficients greater than $0.5(P<0.005)$ (Table 3$)$ predominate in the groundwater: $\mathrm{Ca}-\mathrm{HCO}_{3}$ (0.7342), $\mathrm{Mg}-\mathrm{HCO}_{3}$ (0.7537), $\mathrm{Na}-\mathrm{HCO}_{3}$ (0.7923), $\mathrm{Na}-\mathrm{Cl}$ (0.7107), $\mathrm{Ca}-\mathrm{NO}_{3}$ (0.5281), $\mathrm{Na}-\mathrm{NO}_{3}$ (0.5751), $\mathrm{Mg}-\mathrm{NO}_{3}$ (0.5748), $\mathrm{K}-\mathrm{SO}_{4}(0.5407)$, and $\mathrm{Mg}-\mathrm{SO}_{4}$ (0.5526). The high correlation coefficient values of these ionic pairs suggest that they may have come from the same source(s) and or have been produced by the same process(es).

\subsection{Hydrochemical facies}

Groundwater in the study area was characterized using Piper (1944) trilinear diagram. [27 and 28] classifications were used to classify the groundwater of the study area into different hydrochemical facies. From the diagram (Figure 3), four (4) different hydrochemical facies namely $\mathrm{Ca}-\mathrm{Mg}-\mathrm{HCO}_{3}, \mathrm{Na}-$ $\mathrm{K}-\mathrm{HCO}_{3}, \mathrm{Na}-\mathrm{K}-\mathrm{Cl}-\mathrm{SO}_{4}$, and $\mathrm{Ca}-\mathrm{Mg}-\mathrm{Cl}-\mathrm{SO}_{4}$ (in the order of geochemical evolution) were deciphered.

The $\mathrm{Ca}-\mathrm{Mg}-\mathrm{HCO}_{3}$ facies (constituting $65 \%$ ) is the most dominant facies in the area and it reflects water from recharge zone and prevalence of rock weathering. The $\mathrm{Ca}-\mathrm{Mg}-\mathrm{Cl}-\mathrm{SO}_{4}$ ranked second in abundance (constituting $25 \%$ ) and it reflects groundwater of reverse ion exchange. $\mathrm{Ca}-\mathrm{Mg}-\mathrm{Cl}-\mathrm{SO}_{4}$ facies is a mixed water type with $\mathrm{Ca}-\mathrm{Mg}-\mathrm{HCO}_{3}$ and $\mathrm{Na}-$ $\mathrm{K}-\mathrm{Cl}-\mathrm{SO}_{4}$ as the two end members. The $\mathrm{Na}-\mathrm{K}-\mathrm{HCO}_{3}$ facies constituted $5 \%$ of the total facie types. This facie reflects base ion exchange; exchange of $\mathrm{Ca}$ and $\mathrm{Mg}$ by $\mathrm{Na}$ and $\mathrm{K}$ in the initial $\mathrm{Ca}-\mathrm{Mg}-\mathrm{HCO}_{3}$ facies. The $\mathrm{Na}-\mathrm{K}-\mathrm{Cl}-\mathrm{SO}_{4}$ facies $(5 \%)$ reflects water formed as a result of evaporation or mixing with seawater or saline water.

A geochemical evolution model may be defined here, with water facies beginning with the $\mathrm{Ca}-\mathrm{Mg}-\mathrm{HCO}_{3}$ to $\mathrm{Na}-\mathrm{K}-$
$\mathrm{HCO}_{3}$, then $\mathrm{Na}-\mathrm{K}-\mathrm{Cl}-\mathrm{SO}_{4}$ and again from $\mathrm{Ca}-\mathrm{Mg}-\mathrm{HCO}_{3}$ to $\mathrm{Ca}-\mathrm{Mg}-\mathrm{Cl}-\mathrm{SO}_{4}$.

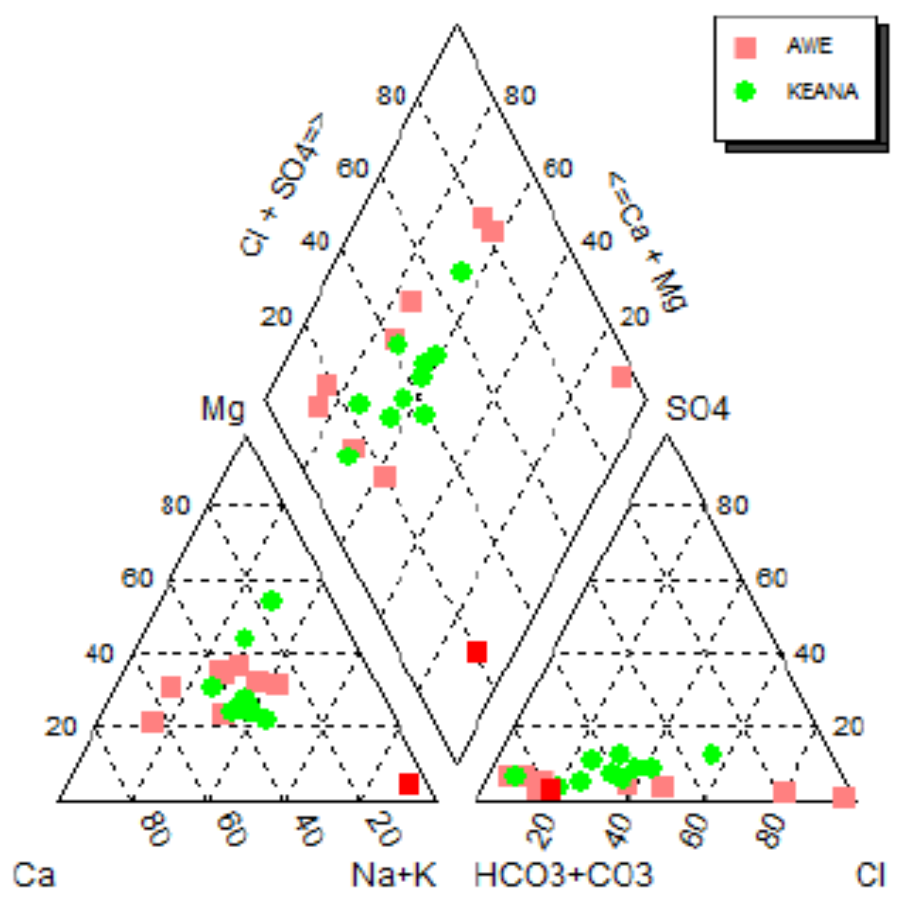

Figure 3. Piper (1944) diagram showing the different hydrochemical facies.

\subsection{Sources of ions}

Gibbs diagram (Figure 4) revealed that rock weathering is the dominant physicochemical process controlling the chemistry of the groundwater in the area. Table 4 presents the saturation indices (SI) in relation to different minerals. The table reveals, that all the groundwater samples were undersaturated $(<0)$ with respect to halite, gypsum, and siderite. Therefore, the concentrations of $\mathrm{Na}$ and $\mathrm{Cl}$ in the groundwater is attributed to the dissolution of halite while $\mathrm{SO}_{4}$ and total $\mathrm{Fe}$ $\left(\mathrm{Fe}^{2+}\right.$ and $\left.\mathrm{Fe}^{3+}\right)$ is attributed to the dissolution of gypsum and siderite respectively. Eleven of the groundwater samples constituting $55 \%$, were undersaturated with respect to both calcite and dolomite, and the remaining nine samples (constituting 45 $\%)$ were oversaturated with respect to calcite and dolomite.

$\mathrm{Ca}$ and $\mathrm{Mg}$ concentrations may be considered to be as a result of the dissolution of calcite and dolomite respectively. It was observed that the samples from Awe area were characterized more with undersaturation of calcite and dolomite while, those from the Keana area were characterized more with oversaturation with respect to calcite and dolomite. The oversaturation with respect to calcite and dolomite is evidenced by the presence of limestone deposits around the Keana segment. No limestone quarries exist around the Awe segment. It is observed that throughout the entire study area, the lateritic cap is very rich in iron and hence the groundwater is super oversaturated with hematite.

The high concentration of $\mathrm{NO}_{3}$ (from 0.32 to $90.23 \mathrm{mg} / \mathrm{l}$ ) detected in some parts of the Awe-Keana saline fields, indicated 
Table 2. Summary Statistics of the Hydrochemical Data.

\begin{tabular}{lccccccc}
\hline Parameter & Unit & Average & Standard Deviation & Coefficient of Variation & Minimum & Maximum & WHO (2008) Limit \\
\hline $\mathrm{pH}$ & $\mathrm{Nil}$ & 6.46 & 0.54 & 8.38 & 5.52 & 7.72 & $6.5-8.5$ \\
$\mathrm{Eh}$ & $\mathrm{mV}$ & 175.3 & 76.35 & 43.55 & 8 & 281 & - \\
$\mathrm{EC}$ & $\mu \mathrm{S} / \mathrm{cm}$ & 591.46 & 349.52 & 59.09 & 56.1 & 1059 & 500 \\
$\mathrm{TDS}$ & $\mathrm{ppm}$ & 396.28 & 234.18 & 59.09 & 37.59 & 709.53 & 500 \\
$\mathrm{Salinity}$ & $\mathrm{Ppt}$ & 0.89 & 3.44 & 389.04 & 0.01 & 15.51 & - \\
$\mathrm{Cl}$ & $\mathrm{ppm}$ & 489.92 & 1905.97 & 389.04 & 5.99 & 8584.95 & 250 \\
$\mathrm{HCO}_{3}$ & $\mathrm{ppm}$ & 285.24 & 253.83 & 88.99 & 0 & 888.2 & 500 \\
$\mathrm{CO}_{3}$ & $\mathrm{ppm}$ & 36.60 & 44.45 & 121.46 & 0 & 120.00 & - \\
$\mathrm{PO}_{4}$ & $\mathrm{ppm}$ & 1.64 & 1.80 & 109.49 & 0 & 5.11 & - \\
$\mathrm{NO}_{3}$ & $\mathrm{ppm}$ & 27.76 & 28.45 & 102.47 & 0.32 & 90.23 & 45 \\
$\mathrm{SO}_{4}$ & $\mathrm{ppm}$ & 24.50 & 19.36 & 79.04 & 2 & 60.00 & 250 \\
$\mathrm{~K}$ & $\mathrm{ppm}$ & 28.19 & 30.60 & 108.54 & 0.84 & 79.18 & - \\
$\mathrm{Na}$ & $\mathrm{ppm}$ & 339.00 & 890.14 & 262.58 & 4.22 & 3024 & - \\
$\mathrm{Ca}$ & $\mathrm{ppm}$ & 58.76 & 38.78 & 66.02 & 3.63 & 137.30 & 75 \\
$\mathrm{Mg}$ & $\mathrm{ppm}$ & 18.20 & 13.73 & 75.40 & 0.96 & 48.66 & 50 \\
\hline
\end{tabular}

Table 3. Pearson's correlation matrix.

\begin{tabular}{|c|c|c|c|c|c|c|c|c|c|c|c|c|c|c|c|}
\hline & $\mathrm{Ca}$ & $\mathrm{Cl}$ & $\mathrm{CO}_{3}$ & EC & Eh & $\mathrm{HCO}_{3}$ & $\mathrm{~K}$ & $\mathrm{Mg}$ & $\mathrm{Na}$ & $\mathrm{NO}_{3}$ & $\mathrm{pH}$ & $\mathrm{PO}_{4}$ & Salinity & $\mathrm{SO}_{4}$ & TDS \\
\hline $\mathrm{Ca}$ & & 0.4881 & 0.2007 & 0.7536 & -0.330 & 0.7342 & 0.6257 & 0.6865 & 0.676 & 0.5281 & -0.056 & 0.4797 & 0.4881 & 0.4229 & 0.7536 \\
\hline $\mathrm{Cl}$ & 0.4881 & & -0.188 & 0.3167 & -0.519 & 0.5583 & 0.3572 & 0.2976 & 0.7107 & 0.5123 & -0.085 & -0.069 & 1 & 0.0259 & 0.3167 \\
\hline $\mathrm{CO}_{3}$ & 0.2007 & -0.188 & & 0.2407 & 0.3795 & 0.1655 & 0.2401 & 0.4752 & -0.258 & 0.164 & 0.001 & -0.059 & -0.188 & 0.8708 & 0.2407 \\
\hline $\mathrm{EC}$ & 0.7536 & 0.3167 & 0.2407 & & -0.133 & 0.5123 & 0.5766 & 0.4375 & 0.4194 & 0.4302 & -0.267 & 0.253 & 0.3167 & 0.4697 & 1 \\
\hline Eh & -0.330 & -0.519 & 0.3795 & -0.133 & & -0.426 & -0.385 & -0.134 & -0.742 & -0.266 & -0.042 & -0.193 & -0.519 & 0.1637 & -0.133 \\
\hline $\mathrm{HCO}_{3}$ & 0.7342 & 0.5583 & 0.1655 & 0.5123 & -0.426 & & 0.3251 & 0.7537 & 0.7973 & 0.8299 & -0.243 & 0.3658 & 0.5583 & 0.2974 & 0.5123 \\
\hline K & 0.6257 & 0.3572 & 0.2401 & 0.5766 & -0.385 & 0.3251 & & 0.3769 & 0.4956 & 0.1127 & 0.1209 & -0.004 & 0.3572 & 0.5407 & 0.5766 \\
\hline $\mathrm{Mg}$ & 0.6865 & 0.2976 & 0.4752 & 0.4375 & -0.134 & 0.7537 & 0.3769 & & 0.4191 & 0.5748 & 0.1711 & 0.2519 & 0.2976 & 0.5526 & 0.4375 \\
\hline $\mathrm{Na}$ & 0.676 & 0.7107 & -0.258 & 0.4194 & -0.742 & 0.7973 & 0.4956 & 0.4191 & & 0.5751 & -0.102 & 0.2689 & 0.7107 & -0.016 & 0.4194 \\
\hline $\mathrm{NO}_{3}$ & 0.5281 & 0.5123 & 0.164 & 0.4302 & -0.266 & 0.8299 & 0.1127 & 0.5748 & 0.5751 & & -0.303 & 0.2829 & 0.5123 & 0.2477 & 0.4302 \\
\hline $\mathrm{pH}$ & -0.056 & -0.085 & 0.001 & -0.267 & -0.042 & -0.243 & 0.1209 & 0.1711 & -0.102 & -0.303 & & -0.33 & -0.085 & -0.017 & -0.267 \\
\hline $\mathrm{PO}_{4}$ & 0.4797 & -0.069 & -0.059 & 0.253 & -0.193 & 0.3658 & -0.004 & 0.2519 & 0.2689 & 0.2829 & -0.33 & & -0.069 & -0.081 & 0.253 \\
\hline Salinity & 0.4881 & 1 & -0.188 & 0.3167 & -0.519 & 0.5583 & 0.3572 & 0.2976 & 0.7107 & 0.5123 & -0.085 & -0.069 & & 0.0259 & 0.3167 \\
\hline $\mathrm{SO}_{4}$ & 0.4229 & 0.0259 & 0.8708 & 0.4697 & 0.1637 & 0.2974 & 0.5407 & 0.5526 & -0.016 & 0.2477 & -0.017 & -0.081 & 0.0259 & & 0.4697 \\
\hline TDS & 0.7536 & 0.3167 & 0.2407 & 1 & -0.133 & 0.5123 & 0.5766 & 0.4375 & 0.4194 & 0.4302 & -0.267 & 0.253 & 0.3167 & 0.4697 & \\
\hline
\end{tabular}

Correlation coefficient $>0.5$ are in bold. 
Table 4. Saturation indices in relation to Calcite $\left(\mathrm{CaCO}_{3}\right)$, Dolomite $\left(\mathrm{CaMg}\left(\mathrm{CO}_{3}\right)_{2}\right)$, Gypsum $\left(\mathrm{CaSO}_{4} \cdot 2 \mathrm{H}_{2} \mathrm{O}\right), \mathrm{Halite}(\mathrm{NaCl}), \mathrm{Hematite}\left(\mathrm{Fe}_{2} \mathrm{O}_{3}\right)$ and Siderite $\left(\mathrm{FeCO}_{3}\right)$ minerals. (nd $=>$ not determined)

\begin{tabular}{lcccccc}
\hline Location & $\mathrm{CaCO}_{3}$ & $\mathrm{CaMg}\left(\mathrm{CO}_{3}\right)_{2}$ & $\mathrm{CaSO}_{4} \cdot 2 \mathrm{H}_{2} \mathrm{O}$ & $\mathrm{NaCl}$ & $\mathrm{Fe}_{2} \mathrm{O}_{3}$ & $\mathrm{FeCO}_{3}$ \\
\hline Awe 1 & -0.17 & -0.45 & -2.62 & -5.42 & nd & nd \\
Awe 2 & -0.28 & -0.63 & -2.65 & -3.35 & nd & nd \\
Awe 3 & -2.33 & -4.69 & -3.81 & nd & 15.42 & -0.36 \\
Awe 4 & -2.44 & -4.81 & -3.43 & nd & 7.88 & -1.08 \\
Awe 5 & -0.58 & -1.25 & -2.82 & -7.16 & 13.50 & -0.28 \\
Awe 6 & 2.10 & 3.68 & -2.10 & -7.75 & 14.37 & -13.17 \\
Awe 7 & 2.10 & 4.02 & -2.18 & -7.08 & 13.46 & -13.40 \\
Awe 8 & -0.11 & -0.32 & -2.46 & -6.90 & 17.00 & -0.08 \\
Awe 9 & -1.46 & -3.44 & -3.14 & -8.52 & 11.99 & -0.98 \\
Awe 10 & -0.98 & -2.27 & -2.75 & -6.46 & 15.20 & -0.45 \\
Keana 11 & 1.90 & 3.49 & -1.92 & -6.75 & 15.22 & -11.27 \\
Keana 12 & 1.78 & 3.42 & -2.11 & -7.09 & 17.49 & -7.47 \\
Keana 13 & 2.04 & 4.12 & -2.11 & -6.44 & 14.70 & -12.11 \\
Keana 14 & 1.72 & 3.09 & -2.12 & -6.75 & 14.90 & -12.47 \\
Keana 15 & 1.72 & 3.15 & -2.22 & -6.72 & 15.96 & -10.58 \\
Keana 16 & 1.73 & 3.69 & -2.54 & -7.19 & 15.48 & -12.94 \\
Keana 17 & -1.46 & -3.16 & -3.76 & -8.70 & 17.80 & 0.18 \\
Keana 18 & 2.00 & 3.78 & -2.16 & -6.59 & 16.43 & -9.15 \\
Keana 19 & -2.52 & -5.22 & -4.29 & -9.12 & 16.41 & -0.28 \\
Keana 20 & -1.97 & -4.24 & nd & -8.38 & 20.56 & -1.68 \\
\hline
\end{tabular}

Table 5. Saturation indices in relation to Calcite $\left(\mathrm{CaCO}_{3}\right)$, Dolomite $\left(\mathrm{CaMg}\left(\mathrm{CO}_{3}\right)_{2}\right)$, Gypsum $\left(\mathrm{CaSO}_{4} \cdot 2 \mathrm{H}_{2} \mathrm{O}\right)$, Halite $(\mathrm{NaCl})$, Hematite $\left(\mathrm{Fe}_{2} \mathrm{O}_{3}\right)$ and Siderite $\left(\mathrm{FeCO}_{3}\right)$ minerals.

\begin{tabular}{|c|c|c|c|}
\hline & PC 1 & PC 2 & PC 3 \\
\hline $\mathrm{Ca}$ & 0.335818 & 0.293805 & 0.135665 \\
\hline $\mathrm{Cl}$ & 0.360345 & -0.105957 & -0.0336973 \\
\hline Eh & 0.307956 & -0.0532982 & -0.234097 \\
\hline $\mathrm{HCO}_{3}$ & 0.374573 & -0.0145737 & 0.00042887 \\
\hline $\mathrm{K}$ & 0.17127 & -0.28981 & 0.591508 \\
\hline $\mathrm{Mg}$ & 0.150976 & 0.554345 & 0.035744 \\
\hline $\mathrm{Na}$ & 0.390315 & -0.0936606 & -0.00266831 \\
\hline $\mathrm{NO}_{3}$ & 0.302649 & -0.060511 & -0.0534841 \\
\hline $\mathrm{pH}$ & -0.0458886 & 0.518323 & -0.336216 \\
\hline Salinity & 0.360345 & -0.105957 & -0.0336973 \\
\hline $\mathrm{SO}_{4}$ & -0.273386 & 0.0726313 & 0.454219 \\
\hline TDS & 0.139542 & 0.458819 & 0.501138 \\
\hline Eigen Value & 5.57428 & 1.84474 & 1.0301 \\
\hline$\%$ of Variance & 46.452 & 15.373 & 8.584 \\
\hline Cumulative $\%$ & 46.452 & 61.825 & 70.409 \\
\hline
\end{tabular}

Table 6. Table of Principal Component Scores.

\begin{tabular}{lccc}
\hline Location & PC 1 & PC 2 & PC 3 \\
\hline Awe 1 & $\mathbf{3 . 9 9}$ & -0.24 & 0.135665 \\
Awe 2 & $\mathbf{8 . 5 0}$ & -0.85 & -0.14 \\
Awe 3 & 0.43 & 0.53 & 0.37 \\
Awe 4 & 0.02 & $\mathbf{1 . 6 3}$ & -0.60 \\
Awe 5 & $\mathbf{- 1 . 6 2}$ & $\mathbf{- 0 . 5 0}$ & $\mathbf{- 1 . 3 2}$ \\
Awe 6 & 0.17 & -0.80 & $\mathbf{- 1 . 4 4}$ \\
Awe 7 & -0.76 & 0.02 & -0.69 \\
Awe 8 & $\mathbf{- 1 . 0 9}$ & -0.52 & $\mathbf{- 1 . 0 8}$ \\
Awe 9 & -0.93 & 0.58 & -0.32 \\
Awe 10 & -0.97 & 0.22 & -0.37 \\
Keana 11 & $\mathbf{- 1 . 9 0}$ & $\mathbf{- 1 . 6 7}$ & $\mathbf{1 . 6 5}$ \\
Keana 12 & $\mathbf{- 1 . 4 6}$ & $\mathbf{- 1 . 5 4}$ & -0.01 \\
Keana 13 & -0.90 & $\mathbf{3 . 3 2}$ & -0.31 \\
Keana 14 & -0.90 & $\mathbf{- 1 . 3 1}$ & $\mathbf{1 . 0 8}$ \\
Keana 15 & $\mathbf{- 1 . 6 6}$ & $\mathbf{- 1 . 0 1}$ & $\mathbf{- 1 . 2 9}$ \\
Keana 16 & 0.31 & -0.90 & -0.41 \\
Keana 17 & -0.45 & $\mathbf{1 . 1 8}$ & 0.99 \\
Keana 18 & -0.90 & $\mathbf{- 1 . 2 2}$ & $\mathbf{1 . 8 8}$ \\
Keana 19 & 0.16 & $\mathbf{1 . 0 8}$ & 1.72 \\
Keana 20 & -0.052 & $\mathbf{2 . 2 0}$ & 0.18 \\
\hline
\end{tabular}


Table 7. Water Quality Index (WQI) Classification for Water of Awe-Keana Area.

\begin{tabular}{lcc}
\hline Location & WQ1 Value & Type of Water \\
\hline Awe 1 & 694.83 & Water Unsuitable for Drinking Purposes \\
Awe 2 & 4181.90 & Water Unsuitable for Drinking Purposes \\
Awe 3 & 127.50 & Poor Water \\
Awe 4 & 93.72 & Good Water \\
Awe 5 & 313.06 & Water Unsuitable for Drinking Purposes \\
Awe 6 & $552 . .58$ & Water Unsuitable for Drinking Purposes \\
Awe 7 & 510.35 & Water Unsuitable for Drinking Purposes \\
Awe 8 & 379.89 & Water Unsuitable for Drinking Purposes \\
Awe 9 & 163.31 & Poor Water \\
Awe 10 & 403.33 & Water Unsuitable for Drinking Purposes \\
Keana 11 & 356.69 & Water Unsuitable for Drinking Purposes \\
Keana 12 & 291.05 & Water Unsuitable for Drinking Purposes \\
Keana 13 & 413.45 & Water Unsuitable for Drinking Purposes \\
Keana 14 & 466.34 & Water Unsuitable for Drinking Purposes \\
Keana 15 & 332.60 & Water Unsuitable for Drinking Purposes \\
Keana 16 & 559.42 & Water Unsuitable for Drinking Purposes \\
Keana 17 & 132.49 & Poor Water \\
Keana 18 & 378.37 & Water Unsuitable for Drinking Purposes \\
Keana 19 & 32.64 & Excellent \\
Keana 20 & 48.51 & Excellent \\
\hline
\end{tabular}

Table 8. Multiple Regression Analysis.

\begin{tabular}{lcccc}
\hline Parameter & Estimate & Standard Error & Statistic & P-Value \\
\hline Constant & $-4.7676 \times 10^{-9}$ & $1.4758 \times 10^{-5}$ & $-3.2303 \times 10^{-4}$ & 0.9997 \\
$\mathrm{Ca}$ & 1.32267 & $3.880021 \times 10^{-7}$ & $3.40875 \times 10^{6}$ & 0.0000 \\
$\mathrm{Cl}$ & 0.3968 & $4.66743 \times 10^{-9}$ & $8.50147 \times 10^{7}$ & 0.0000 \\
$\mathrm{HCO}_{3}$ & 0.1984 & $7.19455 \times 10^{-8}$ & $2.75764 \times 10^{6}$ & 0.0000 \\
$\mathrm{Mg}$ & 1.984 & $9.96068 \times 10^{-7}$ & $1.99183 \times 10^{6}$ & 0.0000 \\
$\mathrm{NO}_{3}$ & 2.20444 & $4.67962 \times 10^{-7}$ & $4.71074 \times 10^{6}$ & 0.0000 \\
$\mathrm{SO}_{4}$ & 0.3968 & $4.7444 \times 10^{-7}$ & $8.36355 \times 10^{5}$ & 0.0000 \\
$\mathrm{TDS}$ & 0.1984 & $4.99819 \times 10^{-8}$ & $3.96943 \times 10^{6}$ & 0.0000 \\
\hline
\end{tabular}


that unconfined aquifers predominate in the area. It was observed further that, nitrate concentrations did not relate linearly with well depth. Most of the nitrate-contaminated groundwater sources are located very close to farmlands and areas with very poor sanitary control and protection (this was from reports obtained during the field investigations and the interaction with the people of the locality). Increased nitrate concentrations in the groundwater of the area could be attributed to wastes emanating from fertilized crop fields and runoffs and discharges from livestock.
A

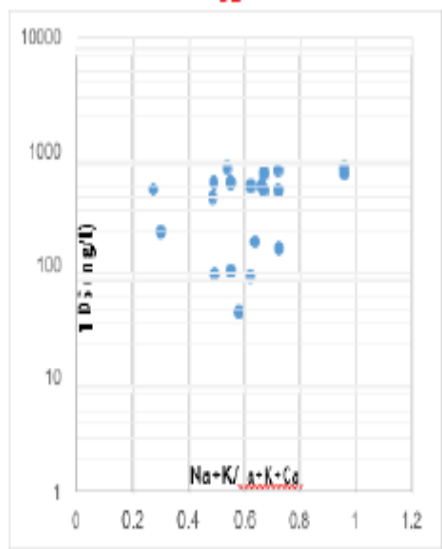

B

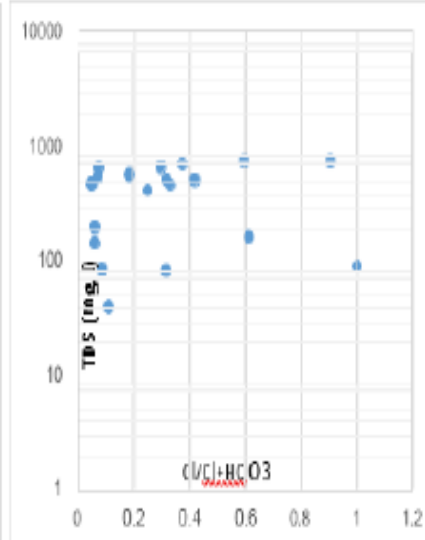

Figure 4. Gibbs diagrams of the hydrochemical data of A) Keana and B) Awe.

\subsection{Statistical analysis}

Cluster analysis (Figure 5) grouped the various sampling stations (20 locations) into two clusters, based on the similarities among the chemical parameters involved in the groundwater quality. Cluster 1: Groundwater characterized with very high salinity, high nitrate contamination and high ionic $(\mathrm{Ca}$, $\mathrm{Cl}, \mathrm{Na}$, and $\mathrm{HCO}_{3}$ ) concentrations and Cluster 2: groundwater with high ionic $\left(\mathrm{Mg}, \mathrm{K}\right.$, and $\left.\mathrm{SO}_{4}\right)$ concentrations.

Table 4 presents the results of Principal component (PC) including component-loading matrix, eigen values, percentage variance and total cumulative variance and cumulative percentage. Three components were extracted that accounted for 70.41 $\%$ of the total variance. PC 1 describes $46.45 \%$ of the total variance and has high positive component-loadings on Eh, salinity, $\mathrm{Ca}, \mathrm{Na}, \mathrm{Cl}, \mathrm{NO}_{3}$, and $\mathrm{HCO}_{3}$. PC 1 could be attributed to weathering and leaching of the host rocks, salinity and nitrate pollution factors.

PC 2 has high positive component-loadings on $\mathrm{pH}, M g$, and TDS and accounts for $15.37 \%$ of the total variance. PC 2 may therefore, be said to reflect TDS factor. The dissolution and migration of the ions are strongly influenced by pH. PC 3 accounted for $8.58 \%$ of the total variance and has high positive loadings on $\mathrm{K}, \mathrm{SO}_{4}$ and TDS, but high negative loadings on $\mathrm{pH}$. This PC reflects the effects of sulphate minerals dissolution.

Principal Component Score (PCS) loadings on the groundwater sample locations are presented in Table 5. PCS loadings at and above \pm 1.0 were considered significant controlling processes on the sample locations. From the table, PC 1 reflect the effect of weathering and leaching of host rocks, salinity and nitrate pollution has high impacts in the groundwater chemistry of sample locations $1,2,5,8,11,12$ and 15 . The chemical composition and chemistry of groundwater of sample locations $4,5,11,12,13,14,15,17,18,19$, and 20 are strongly influenced by TDS, while those of sample locations 5, 6, 8, 11, 14, 15 , and 18 are strongly influenced by sulphate minerals dissolution. Figure 6 presents the distributions and spatial relationships between sampling point loading characteristics.

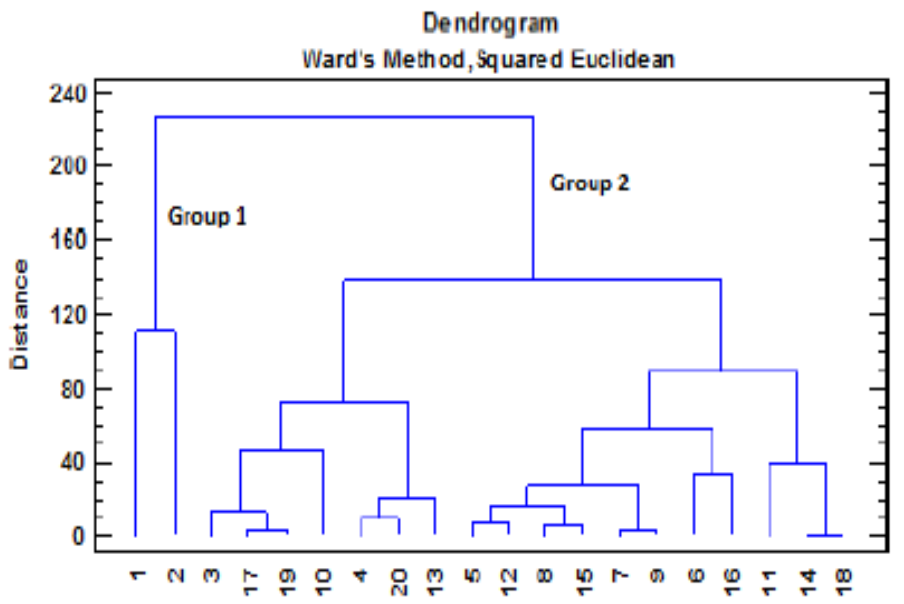

Figure 5. Cluster analysis dendrogram showing the different water classes.

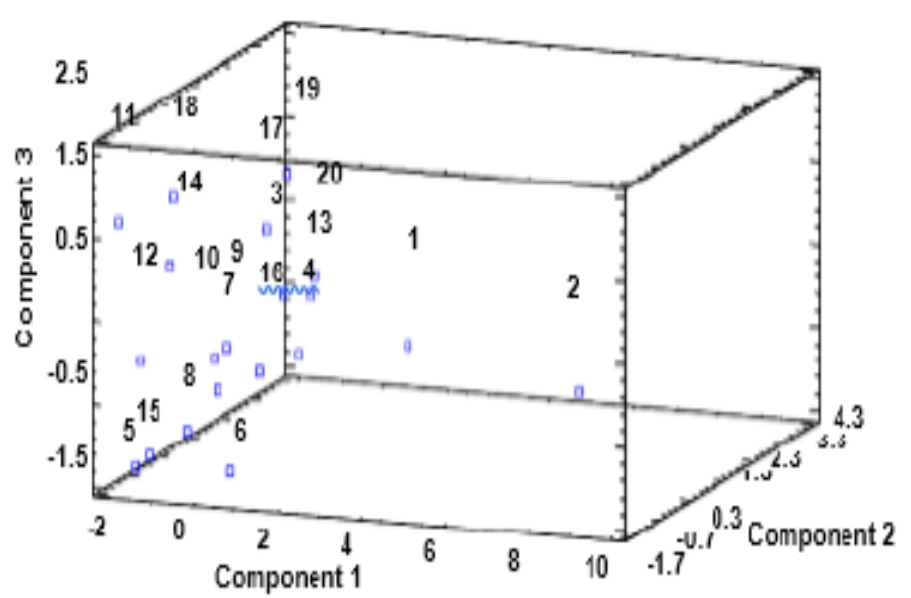

Figure 6. Principal component score scatterplot for the Awe-Keana area.

\subsection{Groundwater quality}

Evaluation of the groundwater quality for drinking and other uses was done through water quality index (WQI). The WQI technique was first introduced by [29] and has been employed by different authors [2, 30, 31, 32 and 33].

The results of the calculated WQI are presented in Table 6 . Four classes of water quality were defined, namely, "excellent 
water" (10\%), "good water" (5\%), "poor water" (15\%) and "water unsuitable for drinking purposes" (70\%). The results showed that groundwater in the area is generally of very poor quality for drinking purposes.

The results of the analysis (Table 7) revealed that nitrate, mainly from nitrate-rich-fertilizers and domestic wastes emanating from septic storages, magnesium and calcium released from dissolutions of dolomite, and calcite minerals in that order are the principal parameters contributing to the pollution and contamination of groundwater of the area.

The suitability of the groundwater for irrigation purposes on the other hand, was evaluated from the [34] Wilcox (USSL, 1954) diagram. From the diagram (Figure 7), groundwater from the area plotted within the following fields, low sodium alkali hazard-low salinity hazard (C1-S1), medium salinity hazardlow sodium alkali hazard (C2-S1), high salinity hazard -low sodium alkali hazard (C3-S1) and high salinity hazard-medium sodium alkali hazard (C3-S2). Most of the groundwater samples plotted within the C1-S1 field and hence, can be used for irrigation. However, those that plotted C3-S2 should be used with caution for irrigation.

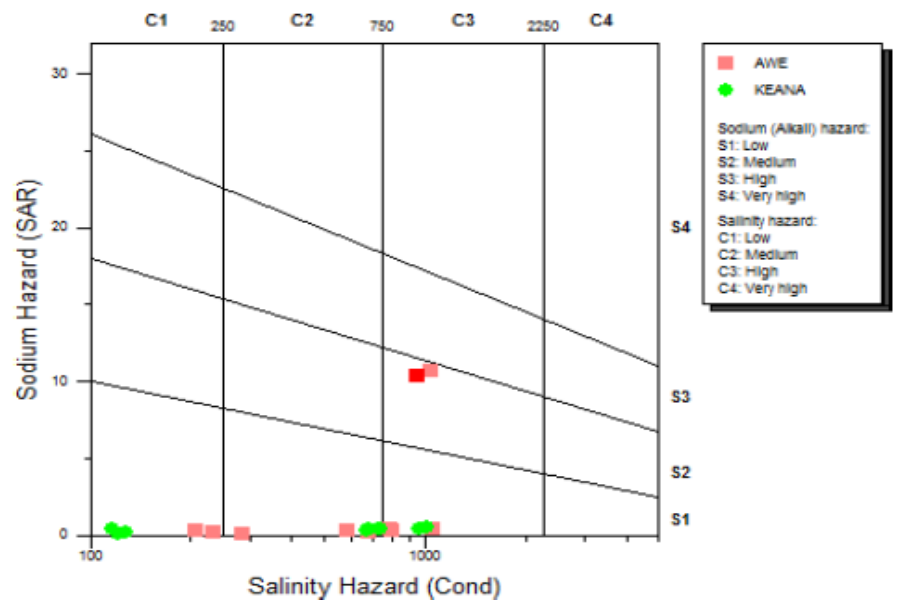

Figure 7. Wilcox diagram for groundwater of the area.

\section{Conclusion}

Hydrochemical characteristics of groundwater from the AweKeana saline field, CBT Nigeria have been studied and different indices used to assess the quality of the groundwater. Results of the hydrochemical analysis revealed that the groundwater in the area is slightly acidic to neutral and that anoxic conditions prevailed during the period the groundwater formation.

The concentrations of the major ions showed high variability which could be attributed to differences in the underlying geologic materials, prevailing lithogenic processes, recharge rates, and anthropogenic factors. Four hydrochemical facies were deciphered, namely, $\mathrm{Ca}-\mathrm{Mg}-\mathrm{HCO}_{3}(65 \%) ; \mathrm{Ca}-\mathrm{Mg}-\mathrm{Cl}-\mathrm{SO}_{4}$ (25\%); $\mathrm{Na}-\mathrm{K}-\mathrm{HCO}_{3}(5 \%)$ and $\mathrm{Na}-\mathrm{K}-\mathrm{Cl}-\mathrm{SO}_{4}(3 \%)$ in that order. The prevalence of the $\mathrm{Ca}-\mathrm{Mg}-\mathrm{HCO}_{3}$ could be attributed to the increased action of $\mathrm{CO}_{2}$ on $\mathrm{H}_{2} \mathrm{O}$, low waterrock interactions rate, and low residence time. Different sources and processes were contributed by the concentration of the various ions in the groundwater. Prominent controlling processes include dissolution and precipitation of calcite and dolomite, precipitation of hematite and dissolution of gypsum, halite and siderite.

Cluster analysis identified two types of sample locations cluster based on their chemical composition similarities (Cluster 1: Groundwater characterized with very high salinity, high nitrate contamination and high ionic $\left(\mathrm{Ca}, \mathrm{Cl}, \mathrm{Na}\right.$, and $\left.\mathrm{HCO}_{3}\right)$ concentrations and Cluster 2: groundwater with high ionic $(\mathrm{Mg}$, $\mathrm{K}$, and $\mathrm{SO}_{4}$ ) concentrations) while principal component analysis revealed three hydrochemical processes controlling the groundwater chemistry (weathering and leaching; dissolution and migration of ions and dissolution of sulphate minerals).

Evaluation of the groundwater quality for drinking and other domestic purposes showed that $85 \%$ of the groundwater sources examined are not potable while only $15 \%$ is suitable for drinking and other domestic purposes. $\mathrm{NO}_{3}$ was found to be the most paramount parameter impairing the quality of groundwater in the area. The groundwater is generally suitable for irrigation particularly for halophytes but not for the cultivation of glycophytes.

\section{Acknowledgments}

We thank the referees for the positive enlightening comments and suggestions, which have greatly helped us in making improvements to this paper.

\section{References}

[1] K. Uma, "The brine fields of the Benue Trough, Nigeria: a comparative study of geomorphic, tectonic and hydrochemical properties" Journal of African Earth Sciences 2 (1998) 261.

[2] N. D. Umar, O. Igwe \& I. G. Idris, "Evaluation and Characterization of Groundwater of the Maastrichtian Lafia Formation, Central Benue Trough, Nigeria" Journal of Earth System Science. J. Earth Syst. Sci. 128 (2019) https://doi.org/10.1007/s12040-019-1199-1.

[3] J. M. Ishaku, A. S. Ahmed \& M. A. Abubakar, "Assessment of groundwater quality using water quality index and GIS in Jada NE Nigeria". International Research Journal of geology and Mining 2 (2012) 54.

[4] P. J. S. Kumar, "Interpretation of groundwater chemistry using piper and Chadha's diagrams": A Comparative study from Perambalur taluk. Elixir Geoscience, (2013) 5412208.

[5] O. S. Onwuka, O. V. Omonona \& O. C. Anika. "Hydrochemical characteristics and quality assessment of regolith aquifers in Enugu metropolis, southeastern Nigeria”. Environmental Earth Sciences 70 (2013) 1135.

[6] O. V. Omonona, O. S. Onwuka, C. O. \& Okogbue, "Characterization of groundwater quality in three settlement areas of Enugu metropolis, southeastern Nigeria”. Environmental monitoring Assessment 186 (2014) 651.

[7] F. A. Akpah, O. S. Onwuka \& I. A. Oha, "Hydrogeochemical investigation and characterization of shallow groundwater within Ankpa Town, North Central Nigeria”. International Journal of Physical Sciences 12 (2017) 60. doi: 10.5897/IJPS2016.4595.

[8] A. K. Tiwari, A. K. Singh \& M. P. Singh, "Hydrogeochemical analysis and evaluation of surface water quality of Pratapgarh district, Uttar Pradesh, India". Applied Water Science 7 (2017) 1609.

[9] N. L. Binbol, "A climate of Nasarawa state; Report of Geographical Prospective on Nasarawa State" Department of Geography, Nasarawa State University Keffi, (2006).

[10] M. E. Offodile, "The Geology of the Middle of Benue Nigeria' Cretaceous Research Paleontological Institute: University of Uppsala Special Publication 4 (1976) 1. 
[11] C. S. Nwajide, "Cretaceous Sedimentation and Paleogeography of the Central Benue Trough" In: C. O. Ofoegbu (ed.), The Benue Tough structure and Evolution International Monograph Series: Braunschweig. (1990) 19.

[12] N.G. Obaje, I. Funtua, B. Ligouis \& S. I. Abaa, "Maceral Associations Organic Maturation and Coal derived Hydrocarbon Potential in the Cretaceous Awgu Formation, Middle Benue Trough, Nigeria" Journal of African Sciences, 1996 pp89.

[13] M. E. Offodile, "The occurrence and exploitation of groundwater in Nigeria basement complex rocks". Journal of Mining Geology 2 (1983) 131.

[14] M. E. Offodile, "Groundwater study and development in Nigeria" Mecon Geology and Engineering Services Ltd. Jos, Nigeria. (2002).

[15] R. W. Puls \& M. J. Barcelona, "Low flow (minimal drawdown) groundwater sampling procedures" United States Environmental Protection Agency (1996) EPA/540/S-95/504.

[16] P. M. Please, K. L. Watkins \& J. A. Bauld. "A groundwater quality assessment of the alluvial aquifers in the Logan-Albert catchment SE Queensland" Australian Geological Survey Organization Record (1996) 48.

[17] K. M. Ivkovic, K. L. Watkins, R. G. Cresswell \& J. Bauld, "A groundwater quality assessment of the fractured rock aquifers of the Piccadilly Valley, South Australia” Australian Geological Survey Organization Record (1998) 16.

[18] K. L. Watkins, K. M. Ivkovic \& J. Bauld, "A groundwater quality assessment of the Goulburn catchment, Victoria: Nagambie-Mangalore" Bureau of Rural Sciences, Canberra (1999).

[19] K. L. Watkins, N. Kulatunga \& J. Bauld, "Groundwater quality of the Murray-Riverina catchment, NSW: Wakool-Cadell and DenimeinBerriquin Regions" Australian Geological Survey Organization Record (1998) 32.

[20] C. R. Ramakrishnaiah, C. Sadashvaiah \& G. Ranganna, "Assessment of water quality Index for the groundwater in Tumkur Taluk, Karnataka state, India"; E-J. Chem. 6 (2009) 523.

[21] R. Reza \& G. Singh, "Assessment of ground water quality status by using water quality Index method in Orissa, India” World Appl. Sci. J. 9 (2010) 1392.

[22] M. Vasanthavigar, K. Srinivasamoorthy, K. Vijayaragavan, R. Ganthi, S.
Chidambaram, P. Anandhan, R. Manivannan \& S. Vasudevan, "Application of water quality for groundwater quality assessment: Thirumanimuttar Sub basin, Tamil Nadu, India” Environmental Monitoring Assessment 171 (2010) 595.

[23] O. V. Omonona, O. S. Onwuka \& C. O. Okogbue, "Characterization of groundwater quality in three settlement areas of Enugu metropolis, southeastern Nigeria, using multivariate analysis" Environmental Monitoring Assessment 186 (2014) 651.

[24] WHO. "Guidelines for drinking - water quality", 2nd edn. World Health Organization, Geneva (2008).

[25] T. K. Boating, F. Opoku, S. O. Acquaah \& O. Akoto, "Groundwater quality assessment using statistical approach and water quality index in Ejisu-Juaben municipality, Ghana" Environmental Earth Sciences (2016) doi:10.1007/s12665-015-5105-0.

[26] C. A. J. Appelo \& D. Postma. Geochemistry, Groundwater and Pollution. A. A. Balkema Publishers, Rotterdam (1993).

[27] M. Bahar \& S. Reza. "Hydrochemical characteristics and quality assessment of shallow groundwater in a coastal area of Southern Bangladesh". Environmental Earth Science 61 (2010) 1065.

[28] R. K. Horton. "An index number system for rating water quality” Journal of Water Pollution Control Federation, 37 (1965).

[29] C. R. Damakrisshnaiah, C. Sadashivaiah \& G. Ranganna. "Assessment of water quality for groundwater in Tumkur Taluk Karnataka State, India" E-Journal of Chemistry 6 (2009) 523.

[30] G. S. Rao \& G. Negeswararao. "Assessment of groundwater quality using water quality index" Arch. Environ. Sci. 7 (2013) 1.

[31] J. Sirajudeen \& R. Abdul Vahith. "Application of water quality for groundwater quality assessment of Tamil Nadu and Pondicherry India" Journal of Environmental Research and Development 8 (2014) 443.

[32] S. Singh \& A. Hussian, "Water quality index development for groundwater quality assessment of groundwater Noida Sub-basin, Uttar Pradesh, India" Cogent Engineering 3 (2016) 1.

[33] USSL. Diagnosis and improvement of saline and alkali soils. USDA Agricultural Handbook (1954) No.60, Washington DC. 